\title{
Hermetism between Camponotus morosus Smith and Linepithema humile Mayr (Hymenoptera: Formicidae)
}

\section{Hermetismo entre Camponotus morosus Smith y Linepithema humile Mayr(Hymenoptera: Formicidae)}

\author{
Joaquín Ipinza-Regla1 ${ }^{1}$ Ana María Fernández ${ }^{1}$, Maria Angélica Morales ${ }^{2}$ \& Jaime E. Araya ${ }^{3 *}$ \\ ${ }^{1}$ Laboratorio de Zoología y Etología, Facultad de Ciencias, Universidad Mayor, Camino La Pirámide, Huechuraba, Santiago, \\ Chile. joaquin.ipinza@umayor.cl \\ ${ }^{2}$ Facultad de Ciencias Pecuarias y Veterinarias, Universidad de Chile, Santa Rosa 11735, La Pintana, Santiago, Chile. \\ ${ }^{3}$ Facultad de Ciencias Agronómicas, Universidad de Chile, Santa Rosa 11315, La Pintana, Santiago, Chile. jaimearaya@ \\ yahoo.com
}

\begin{abstract}
Hermetism, a behavior that isolates ant colonies, was studied in the laboratory between two ant species in Chile, Camponotus morosus Smith and Linepithema humile Mayr. Ants from five nests of C. morosus and L. humile were used, transferring ten individuals per nest of one of the colonies to receiving nests of the other. Conducts, including antennal exploration (AE), mandible opening (MO), dorsal flexion of the abdomen (DFA), biting (Bi), ventral flexion of the abdomen (VFA), fight (Fi), transport of the intruder ant (TI), moving backwards (MB), and death (De) were recorded during ten min, with ten replicates. The times of occurrence $\pm \mathrm{SD}$ of each event were analyzed with the Student $t$ test. The events AE, MO, DFA, and MB had a short latency time in receiving L. humile, while C. morosus presented lesser latency for the events Bi, VFA, and Fi. When analyzing by $\chi^{2}$ the frequency of occurrence of each event per species, AE and MO were similar in both species, and in aggression and rejection events like DFA, Bi, VFA, Fi, MB, TI, and De, there were greater frequencies of observations in C. morosus that in L. humile. From these results, C. morosus is a more hermetic ant than L. humile.
\end{abstract}

KEYwords: Behavior events, artificial nests, Chile.

\section{RESUMEN}

Se estudió en laboratorio el hermetismo, un comportamiento de aislación entre colonias entre dos especies de hormigas en Chile, Camponotus morosus Smith y Linepithema humile Mayr. Se utilizaron hormigas desde cinco nidos de C. morosus y L. humile, y se transfirieron diez individuos por nido desde una de las colonias hacia nidos receptores de la otra. Las conductas se grabaron durante $10 \mathrm{~min}$, incluyendo exploración con las antenas (EA), abertura mandibular (AM), flexión dorsal del abdomen (FDA), mordedura (Mo), flexión ventral of del abdomen (FVA), vuelo (Vu), transporte de la hormiga intrusa (TI), retroceso $(\mathrm{Re})$ y muerte $(\mathrm{Mu})$, con diez repeticiones El tiempo de desarrollo \pm DS de cada evento se analizó con el test $\mathrm{t}$ de Student. Los eventos EA, AM, FDA y Re tuvieron un tiempo de latencia corto al recibir a L. humile, mientras que $C$. morosus presentó menor latencia en los eventos Mo, FVA y Vu. Al analizar mediante $\chi^{2}$ la frecuencia de ocurrencia de cada evento, EA y AM fueron similares en ambas especies, y en los evento de agresión y rechazo como FDA, Mo, FVA, $\mathrm{Vu}, \mathrm{Re}, \mathrm{TI}$ y Mu hubo mayor frecuencia de observaciones en C. morosus que en L. humile. Con estos resultados, $C$. morosus es una hormiga más hermética que L. humile.

Palabras clave: Eventos conductuales, nidos artificiales, Chile.

\section{INTRODUCTION}

In Chile, there are 62 species of ants described (Snelling \& Hunt 1975, Ipinza-Regla 1984), distributed in six subfamilies, for of them more important for their number and distribution, Ponerinae, Dolichoderinae, Myrmicinae, and Formicidae (Ipinza-Regla 1984), which are found from
Arica through Tierra del Fuego, with a longitudinal transect from sea level through $2540 \mathrm{~m}$ elevation (Ipinza-Regla et al. 1983).

Social insects may recognize their sisters by means of mechanisms base don visual, sonic, and tactile/olfactory signals. In ants, recognition is based in cuticle chemical markers, hydrocarbon molecules synthesized in the colony, 
that give a particular odor to each nest, which is recognized by the olfactory receptors in the antennae (Lahav et al. 1999; Katzav-Gozansky et al. 2004).

The differentiation between ants of the same species but different colonies is based in the recognition of these chemical markers (Jaisson 1985).

Ant societies are considered hermetic, that is, they do no accept individuals from another colony, either congeneric or not (Ipinza-Regla et al. 1996). Hermetism is recognized by violent aggressive reactions of the resident ants toward those homo- or hetero-specific intruders, which are often killed. The degree of hermetism is affected by the number of queens in the colony (monoginy or poliginy), the age of the intruder, the distance between nests and the removal of the colony (Ipinza-Regla et al. 1991).

Herein we evaluated in the laboratory the behavior parameters of rejection and tolerance (hermetism) toward an intruder in artificial nests of two ant species, Camponotus morosus Smith, 1858, and Linepithema humile Mayr, 1868, observing and comparing the frequency and latency time of these events.

\section{MATERIALS AND METHODS}

Eighty to 100 ants and a variable number of eggs and larvae were collected from five nests of the ants $C$. morosus (nests A1-A5) in San Carlos de Apoquindo, a pre-Andean location in the Las Condes Commune, Santiago, Chile, and L. humile (nests B1-B5) on the La Pirámide mountain, Metropolitan Park, Huechuraba Commune, Santiago. This material was taken to the Zoology and Ethology Laboratory, Agronomy School, Universidad Mayor, and set in $10 \times 30 \times 10 \mathrm{~cm}$ plastic rearing boxes that were maintained at $20 \pm 2^{\circ} \mathrm{C}, 45$ $50 \% \mathrm{RH}$ and a $12 \mathrm{~h}$ photoperiod under white fluorescent light (Ipinza-Regla et al. 1991). The diet was honey mixed with apple puree and some insects or small pieces of chicken meat as energy and protein sources. Water was provided in wet cotton in glass tubes.

The ants had 30 days acclimation to the artificial nests, after which individuals were transferred to observe the hermetism conducts between the resident and intruding ants, until completion of ten replications with the five nests representing each species:

1) Ten ants from nest A (C. morosus intruders) were transferred individually to nest B (L. humile resident), the conducts were observed during $10 \mathrm{~min}$ and then they were taken away. The latency time of the conduct events was registered form the introduction of each intruding ant (time 0) until the first detection of each conduct action of the resident ant.

2) Vice-versa, ants of nest B (L. humile intruders) were transferred to nest A (C. morosus resident).

The conduct parameters registered were antennal exploration (AE), mandible opening (MO), dorsal flexion of the abdomen (DFA), biting (Bi), ventral flexion of the abdomen (VFA), fight (Fi), transport of the intruder (TI), movement backward (MB), and death (De).

Statistical analysis. The parameter results were analyzed with the Chi square test $\left(\chi^{2}\right)$ to determine the significance of the difference between the numbers of observations (frequency) of each event between both species. Also, for the latency time variable the means and standard deviation (SD) were calculated, and the Student $t$ test was used to determine the significance of the differences between the mean latency (occurrence) times of each conduct event.

\section{RESULTS}

In the transferences from nests $\mathrm{A}$ (C. morosus) to the receiving nests $\mathrm{B}$ (L. humile), and vice-versa, the events AE (antennal exploration) and $\mathrm{MO}$ (mandible opening) occurred always $(100 \%)$ in both species, either as receptors or intruders (Table 1). Both recognition events occur simultaneously (Ipinza-Regla 2008a, 2008b, Hefetz et al. 1996).

The dorsal flexion of the abdomen (DFA) was observed in both species. As resident, C. morosus had a significantly greater frequency $(92.8 \%)$ than $L$. humile $(73.2 \%)$, according to the $\mathrm{Chi}^{2}$ test. Biting (Bi) was observed in both species as residents, with a significantly greater frequency in C. morosus (48.8\%) than L. humile (15.2\%).

As in the previous event, the ventral flexion of the abdomen (VFA) occurred in both species, with a significantly greater frequency in receiving C. morosus $(34.4 \%)$ than in receiving $L$. humile $(8.0 \%)$.

Fighting (Fi) was significantly more frequent in $C$. morosus $(24.0 \%)$ than L. humile (5.6\%).

The transport of the intruder (TI) occurred only in receiving C. morosus (26.0\%), and did not occur in receiving L. humile.

Moving backwards (MB) was observed in both species as receptors, but significantly more frequently in $C$. morosus (33.2\%) than L. humile (16.4\%).

Lastly, the death of the intruder (De), as its transport (TI) occurred only in the receiving nests of C. morosus, with a frequency of $26.0 \%$.

The order of occurrence of the conduct events for the transferences of each species (from B toward A and viceversa), is presented in Table 2 . The events of antennal exploration (AE), mandible opening (MO), and dorsal flexion of the abdomen (DFA) occurred in both transferences and in the same order of occurrence. It calls the attention that the transport of the intruder (TI) and its death (De) was not observed in receiving L. humile.

Antennal exploration (AE) and mandible opening (MO) were the first events to appear and they occurred jointly. 
The means of the events observed in each transference were grouped for species and are presented in Table 2, and their latency times in Table 3.

Latency time of antennal exploration (AE) was significantly shorter in L. humile $(14.01 \mathrm{sec})$ than C. morosus $(18.23 \mathrm{sec})(\mathrm{t}=2.494 ; \mathrm{p}=0.01)$.

Mandible opening (MO) presented a latency time for $C$. morosus receiving of $18.53 \mathrm{sec}$, and $14.16 \mathrm{sec}$ for L. humile receiving $(\mathrm{t}=2.53$; $\mathrm{p}=0.01)$.

Latency time for dorsal flexion of the abdomen (DFA) was also significantly greater for C. morosus $(56.36 \mathrm{sec})$ than $L$. humile receiving $(37.37 \mathrm{sec}) .(\mathrm{t}=2.952 ; \mathrm{p}=0.0033)$.
Latency time for fighting ( $\mathrm{Fi}$ ) tended to occur earlier in C. morosus $(143.9 \mathrm{sec})$ than in L. humile $(179.07 \mathrm{sec})$, but with not a significant difference $(t=0.779 ; \mathrm{p}=0.4384)$.

The transport of the intruder (TI) was observed only in C. morosus receiving, with a latency time of $214.0 \mathrm{sec}$.

The movement backward (MB) event tended to occur earlier in L. humile (137.0 sec) than C. morosus (174.0 $\mathrm{sec})$, but the statistical analysis did not find a significant difference $(\mathrm{t}=1.151 ; \mathrm{p}=0.2519)$.

The death of the intruder (De) occurred only in $C$. morosus receiving, with a latency time of $188.0 \mathrm{sec}$.

TABLE 1. Occurrence frequencies of the conduct events in the transferences of C. morosus (A) toward L. humile (B), and vice-versa. / Frecuencias de eventos conductuales en las transferencias de C. morosus (A) hacia L. humile (B) y viceversa.

\begin{tabular}{|c|c|c|c|c|c|c|}
\hline \multirow[b]{2}{*}{ Events $^{1}$} & \multicolumn{2}{|c|}{$\begin{array}{c}\text { A toward } \mathrm{B} \\
\text { L. humile receiving }\end{array}$} & \multicolumn{2}{|c|}{$\begin{array}{c}\mathrm{B} \text { toward } \mathrm{A} \\
\text { C. morosus receiving }\end{array}$} & \multirow{2}{*}{$\begin{array}{c}\text { Chi } \\
\text { square } \\
\left(\chi^{2}\right)\end{array}$} & \multirow[b]{2}{*}{$\mathrm{p}^{3}$} \\
\hline & $\mathrm{N}^{2}$ & $\%$ & $\mathrm{~N}^{2}$ & $\%$ & & \\
\hline $\mathrm{AE}$ & 250.0 & 100.0 & 250.0 & 100.0 & --- & --- \\
\hline MO & 250.0 & 100.0 & 250.0 & 100.0 & --- & --- \\
\hline DFA & 183.0 & 73.2 & 232.0 & 92.8 & 20.22 & $<0.05$ \\
\hline $\mathrm{Bi}$ & 38.0 & 15.2 & 117.0 & 46.8 & 56.88 & $<0.05$ \\
\hline VFA & 20.0 & 8.0 & 86.0 & 34.4 & 50.58 & $<0.05$ \\
\hline $\mathrm{Fi}$ & 14.0 & 5.6 & 60.0 & 24.0 & 32.12 & $<0.05$ \\
\hline $\mathrm{TI}$ & 0.0 & 0.0 & 43.0 & 17.2 & 44.88 & $<0.05$ \\
\hline MB & 41.0 & 16.4 & 83.0 & 33.2 & 18.03 & $<0.05$ \\
\hline De & 0.0 & 0.0 & 65.0 & 26.0 & 72.43 & $<0.05$ \\
\hline
\end{tabular}

${ }^{1}$ Conduct events, AE: antennal exploration; MO: mandible opening; DFA: dorsal flexion of the abdomen; Bi: biting; VFA: ventral flexion of the abdomen; Fi: fight; TI: transport of the intruder; MB: moving back; De: death.

${ }^{2}$ Number of events observed in a total of 250 transferences.

${ }^{3}$ Probability.

TABLE 2. Order of occurrence of the conduct events in each receiving ant (C. morosus, A, or L. humile, B). / Orden de desarrollo de los eventos conductuales en cada especie de hormiga receptora (C. morosus, A, o L. humile, B).

\begin{tabular}{cccccccccc}
\hline \multirow{2}{*}{ Transferences } & \multicolumn{1}{c}{ Conduct events $^{1}$} \\
\cline { 2 - 10 } & AE & MO & DFA & Bi & VFA & Fi & TI & MB & De \\
\hline B toward A & $1^{\circ}$ & $2^{\text {o }}$ & $3^{\circ}$ & $4^{\circ}$ & $6^{\circ}$ & $5^{\circ}$ & $9^{\circ}$ & $7^{\circ}$ & $8^{\circ}$ \\
A toward B & $1^{\circ}$ & $2^{\circ}$ & $3^{\circ}$ & $5^{\circ}$ & $6^{\circ}$ & $7^{\circ}$ & --- & $4^{\circ}$ & --- \\
\hline
\end{tabular}

${ }^{1}$ Conduct events, AE: antennal exploration; MO: mandible opening; DFA: dorsal flexion of the abdomen; Bi: biting; VFA: ventral flexion of the abdomen; Fi: fight; TI: transport of the intruder; MB: moving back; De: death. 
Hermetism between two ant species: IpINZA-RegLA, J. ET AL.

TABLE 3. Latency times (sec) of the conduct events in the transferences from L. humile (B) toward C. morosus (A), and vice-versa. / Tiempos de latencia times (seg) de los eventos conductuales en las transferencias de L. humile (B) hacia C. morosus (A) y vice-versa.

\begin{tabular}{|c|c|c|c|}
\hline \multirow{2}{*}{ Conduct events ${ }^{1}$} & \multicolumn{2}{|c|}{ Transferences of } & \multirow{2}{*}{$\begin{array}{c}\text { Student } \\
\text { t test }\end{array}$} \\
\hline & B toward A & A toward B & \\
\hline $\mathrm{AE}$ & $\begin{array}{c}\mathrm{n}=250 \\
\mathrm{x}=18.23 \mathrm{sec} \\
\mathrm{SD}=24.22 \mathrm{sec}\end{array}$ & $\begin{array}{c}\mathrm{n}=250 \\
\mathrm{x}=14.01 \mathrm{sec} \\
\mathrm{SD}=11.37 \mathrm{sec}\end{array}$ & $\begin{aligned} \mathrm{t} & =2.494 \\
\mathrm{p} & =0.0130\end{aligned}$ \\
\hline MO & $\begin{array}{c}\mathrm{n}=250 \\
\mathrm{x}=18.53 \mathrm{sec} \\
\mathrm{SD}=24.45 \mathrm{sec}\end{array}$ & $\begin{array}{c}\mathrm{n}=250 \\
\mathrm{x}=14.16 \mathrm{sec} \\
\mathrm{SD}=11.42 \mathrm{sec}\end{array}$ & $\begin{array}{c}\mathrm{t}=2.557 \\
\mathrm{p}=0.0108\end{array}$ \\
\hline DFA & $\begin{array}{c}\mathrm{n}=232 \\
\mathrm{x}=56.36 \mathrm{sec} \\
\mathrm{SD}=81.12 \mathrm{sec}\end{array}$ & $\begin{array}{c}\mathrm{n}=183 \\
\mathrm{x}=37.37 \mathrm{sec} \\
\mathrm{SD}=35.38 \mathrm{sec}\end{array}$ & $\begin{array}{l}\mathrm{t}=2.952 \\
\mathrm{p}=0.0033\end{array}$ \\
\hline $\mathrm{Bi}$ & $\begin{array}{c}\mathrm{n}=117 \\
\mathrm{x}=138.85 \mathrm{sec} \\
\mathrm{SD}=139.61 \mathrm{sec}\end{array}$ & $\begin{array}{c}\mathrm{n}=38 \\
\mathrm{x}=156.42 \mathrm{sec} \\
\mathrm{SD}=70.11 \mathrm{sec}\end{array}$ & $\begin{aligned} \mathrm{t} & =0.745 \\
\mathrm{p} & =0.4575\end{aligned}$ \\
\hline VFA & $\begin{array}{c}\mathrm{n}=86 \\
\mathrm{x}=161.12 \mathrm{sec} \\
\mathrm{SD}=150.95 \mathrm{sec}\end{array}$ & $\begin{array}{c}\mathrm{n}=20 \\
\mathrm{x}=163.45 \mathrm{sec} \\
\mathrm{SD}=122.01 \mathrm{sec}\end{array}$ & $\begin{array}{c}\mathrm{t}=0.064 \\
\mathrm{p}=0.9488\end{array}$ \\
\hline $\mathrm{Fi}$ & $\begin{array}{c}n=60 \\
\mathrm{x}=143.90 \mathrm{sec} \\
\mathrm{SD}=157.13 \mathrm{sec}\end{array}$ & $\begin{array}{c}\mathrm{n}=14 \\
\mathrm{x}=179.07 \mathrm{sec} \\
\mathrm{SD}=126.68 \mathrm{sec}\end{array}$ & $\begin{array}{c}\mathrm{t}=0.779 \\
\mathrm{p}=0.4384\end{array}$ \\
\hline TI & $\begin{array}{c}\mathrm{n}=43 \\
\mathrm{x}=214.14 \mathrm{sec} \\
\mathrm{SD}=180.56 \mathrm{sec}\end{array}$ & $\begin{array}{c}\mathrm{n}=0 \\
\mathrm{x}=0.00 \mathrm{sec} \\
\mathrm{SD}=0.00 \mathrm{sec}\end{array}$ & $\begin{array}{l}t=-- \\
p=---\end{array}$ \\
\hline $\mathrm{MB}$ & $\begin{array}{c}\mathrm{n}=83 \\
\mathrm{x}=174.07 \mathrm{sec} \\
\mathrm{SD}=174.65 \mathrm{sec}\end{array}$ & $\begin{array}{c}\mathrm{n}=41 \\
\mathrm{x}=137.83 \mathrm{sec} \\
\mathrm{SD}=142.98 \mathrm{sec}\end{array}$ & $\begin{array}{c}\mathrm{t}=1.151 \\
\mathrm{p}=0.2519\end{array}$ \\
\hline $\mathrm{De}$ & $\begin{array}{c}\mathrm{n}=65 \\
\mathrm{x}=188.57 \mathrm{sec} \\
\mathrm{SD}=147.75 \mathrm{sec}\end{array}$ & $\begin{array}{c}\mathrm{n}=0 \\
\mathrm{x}=0.00 \mathrm{sec} \\
\mathrm{SD}=0.00 \mathrm{sec}\end{array}$ & $\begin{array}{l}t=-- \\
p=--\end{array}$ \\
\hline
\end{tabular}

${ }^{1}$ Conduct events, AE: antennal exploration; MO: mandible opening; DFA: dorsal flexion of the abdomen; Bi: biting; VFA: ventral flexion of the abdomen; Fi: fight; TI: transport of the intruder; MB: moving back; De: death. n: number of events observed in a total of 250 transferences.

\section{DISCUSSION}

Although the conduct events of antennal exploration (AE), mandible opening (MO), dorsal flexion of the abdomen (DFA), and moving backward (MB) appeared in less seconds in L. humile than C. morosus, the first two events are recognition expressions, that is, they are not agonistic type conducts (e.g., Ipinza-Regla et al. 2005, 2010, 2013).
When two ants meet, they recognize each other at short distance $(1.2 \mathrm{~cm})$, but generally they need physical contact through antennal exploration of any part of the body for recognition, as the signal is distributed broadly in the epicuticle (Lenoir et al. 2001). The events of dorsal flexion of the abdomen (DFA) and moving backward (MB) are considered aggresive conducts, and moving backward is a strategy to avoid homo or heteroespecific contact with the 
intruder species. The events of biting, ventral flexion of the abdomen, and fighting tended to present shorter latency times in C. morosus than in L. humile. Despite the absence of statistical differences, our results agree with the relatively low levels of aggression of C. morosus among three species of ants towards homo- or heteroespecific intruders obtained by Ipinza-Regla et al. (1996).

The degree of tolerance of C. morosus varies toward the introduction of individuals foreign to the nest. For example, C. morosus is more tolerant to the transference of Brachymyrmex giardii Emery when this comes from a monoespecific nest (formed only by $B$. giardii). This could indicate that the presence of ants of several species in the same nest could have a protecting effect on the intruder, which is less rejected when coming from a mixed site (Orivel et al. 1997).

Generally, the members of a nest of social insects are relatives (Crozier \& Pamilo 1996). In most social insects, the individuals recognize their relatives in the nest, and reject the conespecific intruders, maintaining the integrity of the colony and ensuring that altruism is directed toward the relatives (Chapuizat et al. 2004). Discrimination between the members of a nest versus intruders occurs by comparing the phenotype of the olfactory signature of each individual that is met by an ant, with a custom olfactory reference, or template, the chemical signature of the ant that initiates the recognition of the intruder. The recognition of the members of the nest is a comparison of the signatures of other individuals with that of their nest (Boulay \& Lenoir 2001). The standard method to study this process in ants is through aggression bioassays (Chapuizat et al. 2004).

The epicuticular hydrocarbons are considered the main chemical signs responsible of recognition among the nest members of ants and wasps (Lenoir et al. 2001, Soroker et al. 2001, Ipinza-Regla et al. 2004), although their role remains in debate (Lenoir et al. 2001). Numerous studies in ants have found correlations between the patterns of epicuticle hydrocarbons and the recognition process among the members of a nest, but few have purified these compounds, like in the desert ant Cataglyphis niger (André), where only the hydrocarbon fraction present in the epicuticle lipids is responsible for recognition (Lahav et al. 1999, Boulay et al. 2000, Hefetz et al. 2000; Lenoir et al. 2001). These hydrocarbons are mainly alcans of low volatility, sometimes accompanied by alkenes and alkines (Jaffe et al. 2002, Katzav-Gozansky et al. 2004).

The odour recognition hydrocarbons may come from the environment and have been carried to the nest by foraging ants, or be genetically determined odors produced by the queen, workers, or other nest members (Soroker et al. 1998), or may also come directly from an individual or from interactions with other individuals (Lahav et al. 1999, Hefetz et al. 2000, 2001). Thus, in any given source of odor acquisition, the large colonies have a uniform and $y$ unique odor (Soroker et al. 2001, Hefetz et al. 2001, Lenoir et al. 2001, Boulay et al. 2004). According to this model, the members of a colony share and exchange recognition signs and the resulting odor of this colony is an average of the individual odors of each ant in the colony (Soroker et al. 1998).

\section{CONCLUSIONS}

Both ant species presented hermetism, which was stronger in C. morosus than in L. humile. Also, both species presented similar conducts of antennal exploration and mandible opening.

The conducts of aggression and rejection presented significant differences in the frequency of occurrence of the conduct parameters dorsal and/or ventral flexion of the abdomen, biting, fighting, transport of the intruder, moving backward and eventual death, and occurred earlier in $C$. morosus than in L. humile.

\section{ACKNOWLEDGEMENTS}

The authors thank the Research and Development Fund of Universidad Mayor (FIDUM).

\section{BIBLIOGRAPHY}

Boulay, R., Katzav-Gozansky, T. Hefetz, A. \& Lenoir, A. 2004. Odour convergence and tolerance between nestmates through throphallaxis and grooming in the ant Camponotus fellah (Dalla Torre). Insectes Sociaux 51:55-61.

Boulay, R. \& Lenoir, A. 2001. Social isolation of mature workers affects nestmate recognition in the ant Camponotus fellah. Behavioural Processes 55:67-73.

Boulay, R., Soroker, V., Godzinska, E.J., Hefetz, A. \& Lenoir, A. 2000. Octopamine reverses the isolation-induced increase of throphallaxis in the carpenter ant Camponotus fellah. Journal of Experimental Biology 203:513-520.

Chapuizat, M., Bernasconi, C. Hoehn, S. \& Reuter, M. 2004. Nestmate recognition in the unicolonial ant Formica paralugubris. Behavioral Ecology 16(1):15-19.

Crozier, R.H. \& Pamilo, P. 1996. Evolution of social insect colonies: sex allocation and kin selection. Oxford University Press, Oxford, UK. 316 p.

Hefetz,A., Boulay, R., Soroker, V. \& Lenoir, A. 2000. Camponotus fellah colony integration: worker individuality necessitates frequent hydrocarbon exchanges. Animal Behaviour 59:1127-1133.

Hefetz, A., Van Der Meer, R., Soroker, V. \& Lahav, S. 2001. Segregation of colony odor in the desert ant Cataglyphis niger. Journal of Chemical Ecology 27(5): 927-942.

IPINZA-RegLA, J. 1984. Las hormigas: una sorprendente sociedad. Naturaleza 2(10):19-21. 
Ipinza-Regla, J., Covarrubias, R. \& Fueyo, R. 1983. Distribución altitudinal de Formicidae en los Andes de Chile Central. Folia Entomológica Mexicana 5:123-128.

Ipinza-Regla, J., Lucero, A. \& Morales, M.A. 1991. Hermetismo en sociedades de Camponotus morosus, Smith, 1858 (Hymenoptera: Formicidae) en nidos artificiales. Revista Chilena de Entomología 19:29-38.

Ipinza-Regla, J., Morales, M.A. \& Aros, V. 1996. Hermetismo entre tres especies de hormigas. Boletín de la Sociedad de Biología de Concepción, Chile 67:33-37.

IpInZA-Regla, J., Morales, M.A. \& Uribe, M. 2004. Identificación y análisis de hidrocarburos cuticulares relacionados al hermetismo de colonias de Camponotus morosus Smith, 1858 (Hymenoptera: Formicidae). Acta Entomológica Chilena 28(2):63-70.

Ipinza-Regla, J., Fernández, A. \& Morales, M.A. 2005. Hermetismo entre Solenopsis gayi Spinola, 1851, y Brachymyrmex giardii Emery, 1894 (Hymenoptera: Formicidae). Gayana Zoología 69(1):27-35.

Ipinza-Regla, J., Castro, L., Eissmann, R. \& Morales, M.A. 2010. Factores que influyen en la distribución de nidos de la hormiga argentina Linepithema humile Mayr (Hymenoptera: Formicidae), en un ecosistema precordillerano de la zona central de Chile. Neotropical Entomology 39(5):686-690.

Ipinza-Regla, J., MaAck, A. \& Morales, M.A. 2013. Closure of Solenopsis gayi (Spinola, 1851) (Hymenoptera: Formicidae), against Reticulitermes flavipes (Kollar, 1837) (Isoptera: Rhinotermitidae), in artificial nests. Acta Entomológica Chilena 33(1-2):23-30.
JAFFe, K., LóPEZ, H. \& Hernández, J.V. 2002. Nestmate recognition signals of the leaf cutting ant Atta laevigata. Journal of Insect Physiology 48:287-295.

JAISSON, P. 1985. Social behavior. In: Comprehensive insect physiology, biochemistry and pharmacology (Eds. Kerkut, G.A. \& Gilbert, L.I.), Chap. 9:673-694. Pergamon Press, Oxford, UK.

Katzav-Gozansky, T., Boulay, R., Van Der Meer, R. \& Hefetz, A. 2004. In-nest environment modulates nestmate recognition in the ant Camponotus fellah. Naturwissenschaften 91(4)186-190.

Lahav, S., Soroker, V., Hefetz, A. \& Van Der Meer, R. 1999. Direct behavioral evidence for hydrocarbons as ant recognition discriminators. Naturwissenschaften 86:246249.

Lenoir, A., D'etorre, P. \& Errard, C. 2001. Chemical ecology and social parasitism in ants. Annual Review of Entomology 46:573-600.

Orivel, J., ERrard, C. \& Dejean, A. 1997. Ant gardens: Interspecific recognition in parabiotic ant species. Behavioral Ecology \& Sociobiology 40:87-93.

Snelling, R. \& Hunt, J.H. 1975. The ants of Chile (Hymenoptera: Formicidae). Revista Chilena de Entomología 9:63-129.

Soroker, V., Fresneau, D. \& Hefetz, A. 1998. Formation of colony odor in Ponerine ant Pachicondyla apicalis. Journal of Chemical Ecology 24(6):1077-1090.

Soroker, V., Lenoir, A., Hefetz, A. \& Simon, T. 2001. Comparative dynamics of gestalt odour formation in two ant species, Camponotus fellah and Aphaenogaster senilis (Hymenoptera: Formicidae). Physiological Entomology 26:275-283. 